\section{Characterization of Bis-Acryl Composite Resins for Provisional Restorations}

Júlia K. Schwantz ${ }^{1}$, Aline Oliveira-Ogliari², Carine T. Meereis², Fernanda B. Leal $^{2}$, Fabrício A. Ogliari, ${ }^{2,3}$, Rafael R. Moraes ${ }^{1,2}$

This study investigated the in vitro performance of the commercial bis-acryl composite resins Systemp C\&B II (SYS, Ivoclar Vivadent), Protemp 4 (PT4, 3M ESPE), Structur 2C (ST2, Voco) and ProviPlast (PVP, Biodinamica). Characterization involved optical (color stability, translucency parameter, fluorescence), surface (roughness, morphology and elemental composition), physical-chemical (viscosity, polymerization kinetics) and mechanical analyses (Poisson ratio, biaxial flexural strength, flexural modulus). Most tests were carried out after $24 \mathrm{~h}$, but optical and mechanical analyses were carried out after storage in water at $37^{\circ} \mathrm{C}$ for 1,15 , and 30 days. Data were statistically analyzed $(\alpha=0.05)$. Most results were material dependent. SYS and PT4 showed stability in color and translucency over time. All materials had similar or higher fluorescence than human enamel. SC2 and PVP showed rougher surfaces than the other bis-acryl composites. Smaller filler particles were observed on the surface of PT4 and PVP compared with the coarser particles from ST2 and SYS. Viscosity readings indicated a thixotropic behavior for all tested materials. SYS had the lowest and PT4 the highest degree of $\mathrm{C}=\mathrm{C}$ conversion after $10 \mathrm{~min}$. In the polymerization kinetics, PT4 had the highest maximum polymerization rate and reached earlier the transition between polymerization autoacceleration and autodeceleration. PT4 and SYS had significantly higher flexural strength and modulus than ST2 and PVP for most storage times. Results for Poisson ratio varied between materials. Longer storage periods were generally associated with higher frequency of catastrophic failures in the flexural tests. In conclusion, the performance of bis-acryl composite resins varied largely among materials.

\author{
'School of Dentistry, \\ UFPel - Universidade Federal de \\ Pelotas, Pelotas, RS, Brazil \\ ${ }^{2}$ Graduate Program in Dentistry, \\ UFPel - Universidade Federal de \\ Pelotas, Pelotas, RS, Brazil \\ ${ }^{3}$ Engineering Materials School, \\ UFPel - Universidade Federal \\ de Pelotas, RS, Brazil
}

Correspondence: Prof. Rafael R. Moraes, Rua Gonçalves Chaves 457, s/505, 96015-560 Pelotas, RS, Brasil. Tel: +55-53-3225-6741. e-mail: moraesrr@gmail.com

Key Words: mechanical strength, optical analyses, physical-chemical properties, surface properties.

\section{Introduction}

Provisional restorations are important for the success of many restorative clinical procedures, including the definition of restoration color, shape and contour, particularly in complex restorative rehabilitations (1). Provisional restorations also protect the prepared abutment teeth and aid in reestablishing occlusal parameters as well as maintaining esthetic and periodontal health conditions $(1,2)$. For decades the material used for preparing provisional restorations was auto polymerizing poly(methyl) methacrylate (PMMA), which is commercially available as powder (polymer) and liquid (monomer). Despite its costeffectiveness in dentistry, PMMA has clinical drawbacks like low color stability and mechanical properties that depend on handling conditions, which often lead to inclusion of voids within restorations.

In the late 1990's, bys-acryl composite resins were first introduced into the dental market. Unlike PMMA, bis-acryl composite resins contain divinyl methacrylate monomers and filler particle loading (3). As result, polymerization shrinkage and exothermic release are potentially reduced, and color stability is improved compared with PMMA (4-6). In addition, bis-acryl composite resins are commercially available for use with automix syringes, increasing costs but with easy handling and reducing air entrapment. Bis-acryl composite resins may be used for virtually all types of interim restorations. In addition, according to manufacturers and a few studies in the literature, these materials may present other improved characteristics compared with PPMA, including higher abrasive resistance and esthetics, lower marginal misfit, lower free monomer elution and improved repair potential (7-13). Some materials also have the possibility of dual polymerization.

Several manufacturers recently introduced different bis-acryl materials into the market, which is an indicative of a trend in dental materials use. However, not much information is available regarding the performance of these provisional materials. Therefore, the aim of this study was to investigate the in vitro performance of commercial bis-acryl composite resins by optical, surface, physicalchemical and mechanical analyses. The study tested the null hypothesis that the bis-acryl composite resins show similar performances in all analyses.

\section{Material and Methods}

This in vitro study was designed to characterize and compare four commercial bis-acryl composite resins (Table 1) using optical, surface, physical-chemical and 
mechanical analyses. Paste and catalyst pastes of each bis-acryl composite resin were mixed with dispensing guns and automix syringes and placed into molds of polyvinyl siloxane impression material (Scan Denso; Yller, Pelotas, RS, Brazil). The composite resin was covered with a polyester stripe and a glass slide for $10 \mathrm{~min}$, the surfaces were rinsed with $70 \%$ ethanol and the specimens ultrasonically cleaned with distilled water for $30 \mathrm{~min}$. For all analyses, the specimens were prepared using the same procedures, with no polishing procedures. Tests were carried out on the surfaces that faced the silicone whenever possible, in order to simulate the clinical use of bis-acryl composite resins. The sample size in each analysis was estimated considering the variability of the tests as observed in pilot studies.

\section{Optical Analyses}

Optical tests were conducted after storing disks $(0.5 \mathrm{~mm}$ thick, $14 \mathrm{~mm}$ diameter) in water at $37^{\circ} \mathrm{C}$ for 1 (baseline), 15 and 30 days $(n=10)$, with the immersion medium renewed every week. Color coordinates were measured in the same disks at each storage time using a digital spectrophotometer (SP60; X-Rite, Grand Rapids, MI, USA) based on the Commission Internationale de L'Eclairage (CIE) system. Readings were made with a white background $\left(L^{*}=93.1\right.$; $\left.a^{*}=1.3 ; b^{*}=5.3\right)$. Color difference $\left(\Delta E_{00}\right)$ was calculated based on the CIEDE2000 method $(14,15)$, according to Equation 1:

$\Delta \mathrm{E}_{00}=\sqrt{\left(\frac{\Delta \mathrm{L}^{\prime}}{\mathrm{k}_{\mathrm{L}} \mathrm{S}_{\mathrm{L}}}\right)^{2}+\left(\frac{\Delta \mathrm{C}^{\prime}}{\mathrm{k}_{\mathrm{C}} \mathrm{S}_{\mathrm{C}}}\right)^{2}+\left(\frac{\Delta \mathrm{H}^{\prime}}{\mathrm{k}_{\mathrm{H}} \mathrm{S}_{\mathrm{H}}}\right)^{2}+\mathrm{R}_{\mathrm{T}}\left(\frac{\Delta \mathrm{C}^{\prime}}{\mathrm{k}_{\mathrm{C}} \mathrm{S}_{\mathrm{C}}}\right) \times\left(\frac{\Delta \mathrm{H}^{\prime}}{\mathrm{k}_{\mathrm{H}} \mathrm{S}_{\mathrm{H}}}\right)}$

where $\Delta \mathrm{L}^{\prime}, \Delta \mathrm{C}^{\prime}$, and $\Delta \mathrm{H}^{\prime}$ are differences in lightness, chroma and hue between two color readings, and $R_{T}$ is the rotation function that accounts for the interaction between chroma and hue differences in the blue region. $S_{L}$, $\mathrm{S}_{\mathrm{C}}$ and $\mathrm{S}_{\mathrm{H}}$ are weighing functions used to adjust the total color difference for variation in perceived magnitude with

Table 1. Bis-acryl composite resins tested

\begin{tabular}{|c|c|c|}
\hline $\begin{array}{l}\text { Material } \\
\text { (code) }\end{array}$ & Manufacturer & Components* \\
\hline $\begin{array}{l}\text { Systemp CAB } \\
\text { II (SYS) }\end{array}$ & $\begin{array}{l}\text { Ivoclar } \\
\text { Vivadent, } \\
\text { Schaan, } \\
\text { Liechtenstein }\end{array}$ & $\begin{array}{c}\text { Polyfunctional } \\
\text { methacrylates, inorganic } \\
\text { fillers, plasticizers, catalysts, } \\
\text { stabilizers, pigments }\end{array}$ \\
\hline $\begin{array}{l}\text { Protemp } \\
4 \text { (PT4) }\end{array}$ & $\begin{array}{l}\text { 3M ESPE, St. } \\
\text { Paul, MN, USA }\end{array}$ & $\begin{array}{l}\text { Functional methacrylate } \\
\text { acid esters }\end{array}$ \\
\hline $\begin{array}{l}\text { Structur } 2 \\
\text { SC (ST2) }\end{array}$ & $\begin{array}{l}\text { Voco, Cuxhaven, } \\
\text { Germany }\end{array}$ & $\begin{array}{c}\text { Methacrylic acid } \\
\text { multifunctional esters }\end{array}$ \\
\hline $\begin{array}{l}\text { ProviPlast } \\
\text { (PVP) }\end{array}$ & $\begin{array}{l}\text { Biodinamica, } \\
\text { Ibiporã, PR, } \\
\text { Brazil }\end{array}$ & $\begin{array}{l}\text { Silicon dioxide, catalysts, } \\
\text { dimethacrylate groups, } \\
\text { inorganic filler, pigments }\end{array}$ \\
\hline
\end{tabular}

*Information provided by the manufacturers. variation in the location of the color coordinate difference between two color readings. $\mathrm{k}_{\mathrm{L}} \mathrm{k}_{\mathrm{C}}$ and $\mathrm{k}_{\mathrm{H}}$ are correction terms for the experimental conditions.

In addition to CIE LAB color readings carried out over the white background, readings were also made over a black background $\left(L^{*}=27.9 ; a^{*}=0.0 ; b^{*}=0.0\right)$ at the same storage periods $(n=10)$. Translucency parameter (TP) was calculated according to Equation 2:

$\mathrm{TP}=\left[\left(\mathrm{L}^{*}{ }_{\mathrm{W}}-\mathrm{L}_{\mathrm{B}}\right)^{2}+\left(\mathrm{a}^{*}{ }_{\mathrm{W}}-\mathrm{a}^{*}{ }_{\mathrm{B}}\right)^{2}+\left(\mathrm{b}^{*}{ }_{\mathrm{W}}-\mathrm{b}^{*}{ }_{\mathrm{B}}\right)^{2}\right]^{1 / 2}$

where $\mathrm{W}$ and $\mathrm{B}$ correspond to the color readings made over the white and black backgrounds, respectively. For fluorescence analysis $(n=5)$, the specimens were placed inside a dark chamber and a UV-LED illumination system (Sistema Fluorescência; Biopdi, São Carlos, SP, Brazil) that irradiated $50 \mathrm{~mW} / \mathrm{cm}^{2}$ energy absorbed by the specimen and returned as fluorescent light, recorded by a computer system. A $2 \mathrm{~mm}^{2}$ central area was selected in each specimen and the emitted fluorescence (\%) was measured and compared as percentage of the default fluorescence emitted by the medium third of the buccal side of a central human incisor used as standard.

\section{Surface Analyses}

Disks (6 $\mathrm{mm}$ diameter, $1 \mathrm{~mm}$ thick) were prepared for each bis-acryl composite resin $(n=3)$ and surface roughness $(\mathrm{Ra}, \mu \mathrm{m})$ was measured with a surface profilometer (SJ201; Mitutoyo, Tokyo, Japan) after $24 \mathrm{~h}$ storage in water at $37^{\circ} \mathrm{C}$. The diamond stylus traversed the surface of each specimen with $0.8 \mathrm{~mm}$ cut-off length, $0.0001 \mu \mathrm{m}$ resolution, $8 \mu \mathrm{m}$ range, $0.5 \mathrm{~mm} / \mathrm{s}$ speed and $4 \mathrm{~mm}$ total length. Three readings were made in each specimen rotating it clockwise at random angles. The three roughness readings for each specimen were averaged. Surface morphology and elemental composition of the materials were analyzed in the same specimens $(n=3)$ by scanning electron microscopy (SEM) equipped with $\mathrm{X}$-ray energy dispersive spectroscopy (EDS), using 15-20 kV and $11 \mathrm{~mm}$ working distance (JSM6610/LV; Jeol, Tokyo, Japan).

\section{Physicochemical Analyses}

Three specimens of each bis-acryl composite resin were tested for each physical-chemical analysis. A parallel plate rheometer (R/S-CPS+; Brookfield Ametek, Middleboro, MA, USA) with a temperature controller was used to measure viscoelastic behavior of the materials. To delay auto polymerization, $1 \%$ mass fraction of butylated hydroxytoluene (Sigma-Aldrich, St. Louis, MO, USA) was mixed with the pastes as inhibitor. A $0.5 \mathrm{~mL}$ volume of each material was dispensed on the lower and the upper plates, with $25 \mathrm{~mm}$ in diameter, and positioned with a $0.05 \mathrm{~mm}$ 
gap between plates. Viscosity (Pa.s) was measured for 30 $\mathrm{s}$ by using 30 counts, $100 \mathrm{~s}^{-1}$ constant shear rate and 23 ${ }^{\circ} \mathrm{C}$ temperature.

Real-time polymerization was evaluated with Fourier transform infrared spectroscopy (Prestige21 spectrometer; Shimadzu, Tokyo, Japan) with a horizontal attenuated total reflectance diamond crystal cell. The polymerization reaction of each material was monitored for $10 \mathrm{~min}$ acquiring $1 \mathrm{scan} / \mathrm{s}$ at $4 \mathrm{~cm}^{-1}$ resolution, with Happ-Genzel apodization and $2.8 \mathrm{~mm} / \mathrm{s}$ mirror speed. The degree of $\mathrm{C}=\mathrm{C}$ conversion (\%) was calculated using a baseline technique considering the intensity of $\mathrm{C}=\mathrm{C}$ stretching vibration (peak height) at $1637 \mathrm{~cm}^{-1}$ and as an internal standard, using the symmetric ring stretching at $1608 \mathrm{~cm}^{-1} . \mathrm{C}=\mathrm{C}$ conversion vs. time data were plotted and Hill 3-parameter non-linear regression was used for curve fitting. Rate of polymerization (Rp) was calculated with these fitted data plots.

\section{Mechanical Analyses}

Biaxial flexural tests were conducted after storing disks (14 mm diameter, $0.5 \mathrm{~mm}$ thick) in water at $37^{\circ} \mathrm{C}$ for 1 , 15 and 30 days $(n=10)$, renewed every week. The tests were performed on a mechanical testing machine (DL500; EMIC, São José dos Pinhais, PR, Brazil) with a ball-on-ring setup. The disk specimens were positioned on the setup and a compressive load was applied at a crosshead speed of $0.5 \mathrm{~mm} / \mathrm{min}$ until failure. Biaxial flexural strength $\left(\sigma_{b f}\right)$ and flexural modulus $\left(E_{f}\right)$ were calculated (16) according to Equations 3 and 4:

$$
\begin{aligned}
& \sigma_{\mathrm{bf}}=\frac{\mathrm{P}}{\mathrm{t}^{2}}\left\{(1+v)\left[0.485 \operatorname{In}\left(\frac{\mathrm{a}}{\mathrm{t}}\right)+0.52\right]+0.48\right\} \\
& \mathrm{E}_{\mathrm{f}}=\left[\frac{\mathrm{dP}}{\mathrm{dW}}\right]\left[\frac{0.5024 \mathrm{a}^{2}}{\mathrm{t}^{3}}\right]
\end{aligned}
$$

where $P$ is the maximum load $(N), t$ the specimen thickness $(\mathrm{mm}), v$ the measured Poisson ratio, a the radius of the knife edge support $(\mathrm{mm})$, and $W$ the central displacement of the specimen $(\mathrm{mm})$. The fractured specimens retrieved after testing were observed under $40 \times$ magnification in order to detect whether the failure was catastrophic (generating fragments) or only generated cracks in the specimen.

Poisson ratio $(v)$ was measured beforehand $(n=3)$ in rectangular specimens $(6 \times 5 \mathrm{~mm}, 1 \mathrm{~mm}$ thick), tested after $24 \mathrm{~h}$ storage in water at $37{ }^{\circ} \mathrm{C}$, using impulse excitation technique (Sonelastic; ATCP Engenharia Física, Ribeirão Preto, SP, Brazil). Elastic modulus and damping were calculated from the sound emitted by the specimen after it suffered a small stroke. The acoustic response is composed by natural vibration frequencies of the specimen, proportional to the elastic modulus and its amplitude declines according to the material's damping. Spectra with frequency and amplitude by flexural-torsional vibration were registered by a software (ATCP Sonelastic 2.0) and $v$ was calculated considering material isotropy.

\section{Statistical Analysis}

Normality and equal variance of data were confirmed beforehand. When more than one factor was taken into account (material and storage time, for instance), data were subjected to two-way analysis of variance with a repeated measures approach (one factor repetition) for color, TP and fluorescence data. The analyses were carried out by SigmaStat 3.5 software (Systat Inc., San Jose, CA, USA). Pairwise multiple comparisons were carried out by the Tukey's post hoc method $(\alpha=0.05)$. For single factor analyses, $95 \%$ confidence intervals for means were calculated. Groups were considered significantly different when the confidence interval boundaries did not overlap.

\section{Results}

Results for $\Delta \mathrm{E}_{00}$, TP and fluorescence are in Figure 1. ST2 and PVP were the only bis-acryl composite resins showing significant color difference after 15 and 30 days of storage. The $\Delta \mathrm{E}_{00}$ values for these two materials were above 2.25 , considered as the $50 \%$ acceptability threshold value for the color difference of dental materials. In addition, ST2 and PVP showed significant reduction in PT over time. The bis-acryl composite resins SYS and PT4 did not show significant alteration in color or PT as function of storage time. Variation in individual CIE LAB color coordinates (Table 2) depended on the tested material. After 30 days of storage, the bis-acryl composite resins generally had no significant reduction in luminosity $\left(L^{*}\right)$. PT4 was the only material that did not show any alteration in $\mathrm{a}^{*}$ and $\mathrm{b}^{*}$ coordinates with time. The fluorescence of PVP was significantly higher than the other materials and it remained stable with time. PT4 showed decreased fluorescence and ST2 increased fluorescence as function of storage time. All materials had similar or higher fluorescence than the human incisor's enamel.

Results for roughness and SEM-EDS analysis are shown in Figure 2. SC2 and PVP showed significantly higher roughness than PT4. In the SEM analysis, PT4 and PVP showed smaller particles (scans were taken with higher magnification) compared to ST2 and SYS, which presented coarser particles. Results of the EDS analysis suggest that the inorganic phase of SYS is composed by borosilicate glass particles, while silica composes predominantly the inorganic phase of the other materials.

The viscosity of only 3 materials was evaluated, since PVP exceeded the upper torque limit of the rheometer. 
SC2 was the most viscous bis-acryl composite resin (Fig. 3), followed by PT4 and SYS. The three tested materials showed thixotropic behavior, with reduction in viscosity as function of time under constant shear rate. Polymerization kinetics and rate profiles of the bis-acryl composite resins are shown in Figure 4. SYS had the lowest and PT4 the highest $\mathrm{C}=\mathrm{C}$ conversion after $10 \mathrm{~min}$. PT4 also had the highest maximum $\mathrm{Rp}$ and reached earlier the transition between autoacceleration and autodeceleration than the

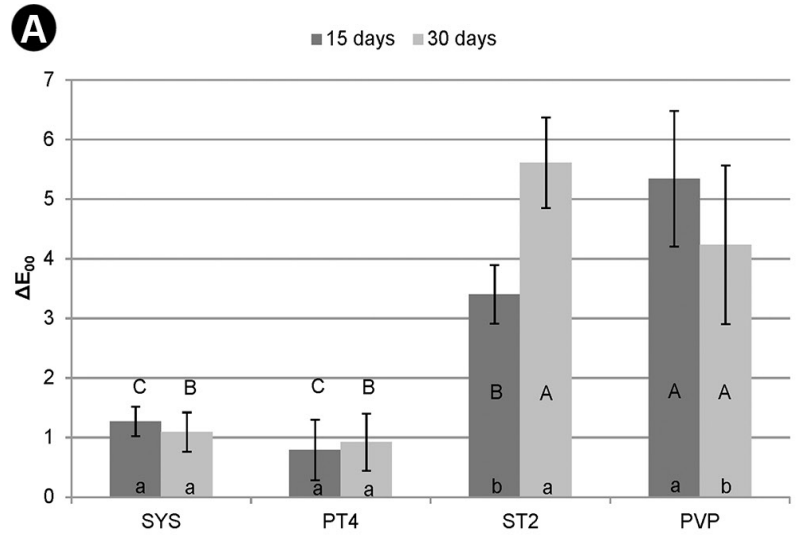

\section{B}

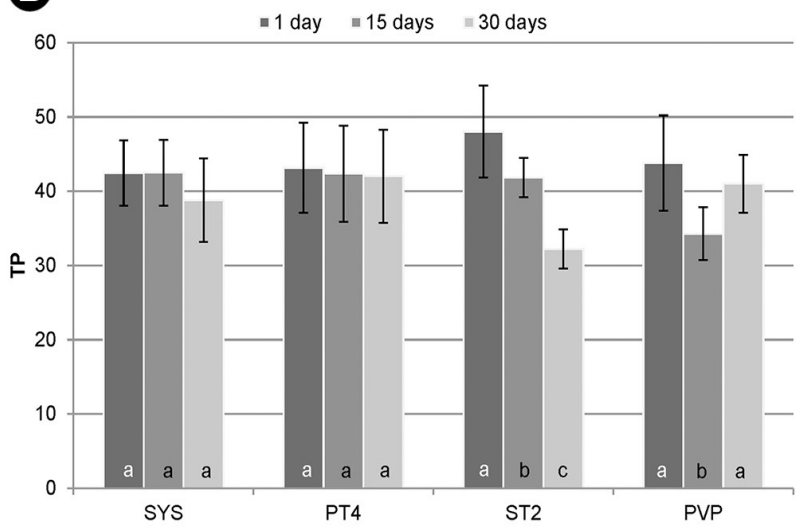

C

- 1 day $=15$ days $\approx 30$ days

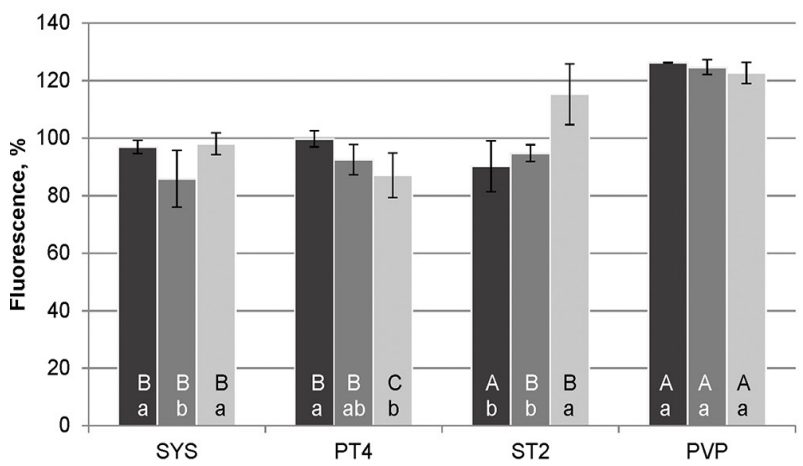

Fig. 1. Means \pm standard deviations for color difference, $\Delta \mathrm{E}_{00}(\mathrm{~A})$, translucency parameter, TP (B), and fluorescence (C). Lowercase letters indicate differences between times for each material. Uppercase letters indicate differences between materials within each storage time. other materials. The material with lowest maximum Rp was SYS, for which the transition from autoacceleration to autodeceleration was hardly perceptible. SYS showed less than $15 \% \mathrm{C}=\mathrm{C}$ conversion at $10 \mathrm{~min}$.

Data for $\sigma_{b f}, E_{f}$ and $v$ are shown in Table 3. PT4 and SYS had significantly higher $\sigma_{b f}$ and $E_{f}$ than ST2 and PVP for most storage times. After 30 days of storage, none of the bis-acryl composite resins had significantly lower mechanical strength. In contrast, in some cases improved mechanical strength was observed after water storage. For ST2 and PVP more than 50\% of the specimens tested under biaxial flexure showed only cracks after failure (Fig. 5). For SYS and PT4, there was an increase in catastrophic failure of specimens after storage. Data for $v$ were used to calculate $\sigma_{b f}$ and varied between materials. Similar results for $v$ were observed between SYS and PVP, and between PT4 and ST2.

\section{Discussion}

This study endeavored to be as comprehensive as possible regarding the evaluation of many aspects that a provisional restorative material should fulfill in order to be clinically used. However, there are no international standards to be considered for addressing target values or allowing discussion whether the findings observed here are within parameters for clinical use of not. One clear aspect observed was the material dependency of most properties

Table 2. Means \pm 95\% confidence intervals for CIE LAB color coordinates $(\mathrm{n}=10)$

\begin{tabular}{|c|c|c|c|c|}
\hline \multirow{2}{*}{ Material } & \multirow{2}{*}{$\begin{array}{l}\text { Storage } \\
\text { time }\end{array}$} & \multicolumn{3}{|c|}{ CIE LAB color coordinates } \\
\hline & & $\mathrm{L}^{*}$ & $a^{*}$ & $b^{*}$ \\
\hline \multirow{3}{*}{$\begin{array}{l}\text { Systemp } \\
\text { CAtB II } \\
\text { (SYS) }\end{array}$} & day & $91.1 \pm 0.4 \mathrm{a}$ & $-1.0 \pm 0.2 b$ & $10.3 \pm 0.3 \mathrm{~b}$ \\
\hline & 15 days & $91.0 \pm 0.3 \mathrm{a}$ & $-0.3 \pm 0.2 \mathrm{a}$ & $11.4 \pm 0.4 \mathrm{a}$ \\
\hline & 30 days & $91.0 \pm 0.5 \mathrm{a}$ & $-0.4 \pm 0.2 \mathrm{a}$ & $10.5 \pm 0.6 \mathrm{ab}$ \\
\hline \multirow{3}{*}{$\begin{array}{l}\text { Protemp } \\
4 \text { (PT4) }\end{array}$} & 1 day & $89.1 \pm 0.2 \mathrm{a}$ & $-0.1 \pm 0.2 \mathrm{a}$ & $11.3 \pm 0.4 \mathrm{a}$ \\
\hline & 15 days & $89.1 \pm 0.4$ a & $-0.1 \pm 0.4 \mathrm{a}$ & $11.4 \pm 0.7 \mathrm{a}$ \\
\hline & 30 days & $88.6 \pm 0.5 \mathrm{a}$ & $0.1 \pm 0.4 \mathrm{a}$ & $11.5 \pm 0.7 \mathrm{a}$ \\
\hline \multirow{3}{*}{$\begin{array}{l}\text { Structur } 2 \\
\text { SC (ST2) }\end{array}$} & 1 day & $85.3 \pm 0.6 \mathrm{~b}$ & $3.4 \pm 0.2 \mathrm{a}$ & $15.4 \pm 0.4 \mathrm{a}$ \\
\hline & 15 days & $86.2 \pm 0.5 b$ & $1.8 \pm 0.4 \mathrm{~b}$ & $10.7 \pm 0.4 \mathrm{c}$ \\
\hline & 30 days & $91.7 \pm 0.3 \mathrm{a}$ & $0.6 \pm 0.4 \mathrm{c}$ & $12.2 \pm 0.4 \mathrm{~b}$ \\
\hline \multirow{3}{*}{$\begin{array}{l}\text { ProviPlast } \\
\text { (PVP) }\end{array}$} & 1 day & $88.7 \pm 2.4 \mathrm{ab}$ & $3.3 \pm 0.4 \mathrm{a}$ & $18.2 \pm 0.5 \mathrm{a}$ \\
\hline & 15 days & $89.9 \pm 0.3 \mathrm{a}$ & $0.8 \pm 0.1 \mathrm{c}$ & $11.3 \pm 0.4 \mathrm{c}$ \\
\hline & 30 days & $87.3 \pm 0.4 b$ & $1.9 \pm 0.2 \mathrm{~b}$ & $12.2 \pm 0.4 \mathrm{~b}$ \\
\hline
\end{tabular}

For each material and color coordinate, distinct letters indicate significant differences between storage times. 
and characteristics investigated herein. Thus, the tested null hypothesis cannot be accepted.

In terms of color stability, two materials (ST2 and PVP) showed significant color difference $\left(\Delta \mathrm{E}_{00} \geq 2.25\right)$ and reduced

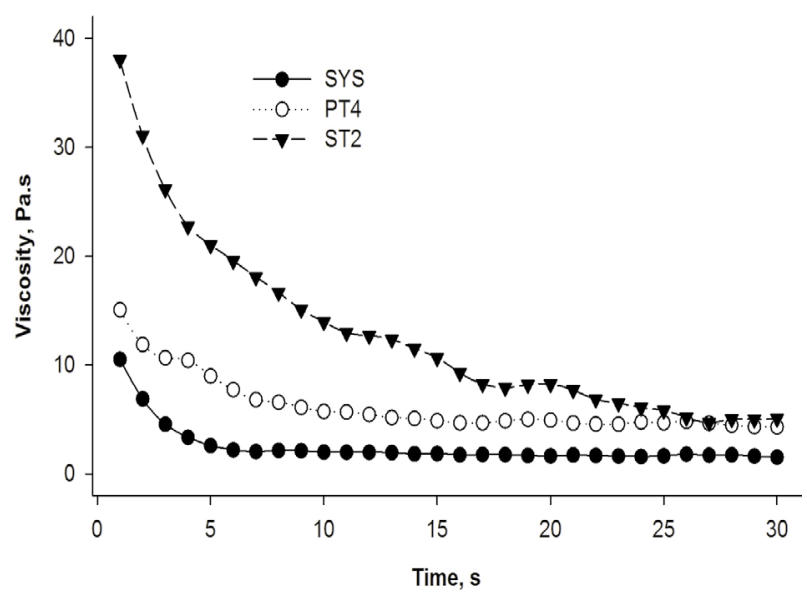

Fig. 3. Results for viscosity of bis-acryl composite resins. Materials showed thixotropic behavior. ProviPlast was not evaluated because its viscosity exceeded upper torque limit of rheometer. translucency during storage, whereas the other materials had stable optical properties. An interim restoration that

Table 3. Means $\pm 95 \%$ confidence intervals for biaxial flexural strength $\left(\sigma_{\mathrm{bf}}, \mathrm{n}=10\right)$, flexural modulus $\left(\mathrm{E}_{\mathrm{f}}, \mathrm{n}=10\right)$, and Poisson ratio $(v, \mathrm{n}=3)$

\begin{tabular}{|c|c|c|c|c|}
\hline Material & $\begin{array}{l}\text { Storage } \\
\text { time }\end{array}$ & $\sigma_{\mathrm{bf}}, \mathrm{MPa}$ & $\mathrm{E}_{\mathrm{f}}, \mathrm{GPa}$ & $v$ \\
\hline \multirow{3}{*}{$\begin{array}{l}\text { Systemp } \\
\text { CAB II } \\
\text { (SYS) }\end{array}$} & 1 day & $36.1 \pm 8.2 \mathrm{AB}, \mathrm{a}$ & $3+11$ & \multirow{3}{*}{$\begin{array}{c}0.21 \\
\pm 0.02 \mathrm{~b}\end{array}$} \\
\hline & 15 days & $40.0 \pm 5.8 \mathrm{AB}, \mathrm{a}$ & $8.1 \pm 1.2$ A.ab & \\
\hline & 30 days & $50.3 \pm 11.7$ A,a & $11.5 \pm 3.3$ A.a & \\
\hline \multirow{3}{*}{$\begin{array}{l}\text { Protemp } \\
4 \text { (PT4) }\end{array}$} & 1 day & $52.6 \pm 11.7 \mathrm{~A}, \mathrm{a}$ & $8.0 \pm 2.7$ A.a & \multirow{3}{*}{$\begin{array}{c}0.30 \\
\pm 0.01 \mathrm{a}\end{array}$} \\
\hline & 15 days & $54.5 \pm 12.7 \mathrm{~A}, \mathrm{a}$ & $9.8 \pm 2.4$ A.a & \\
\hline & 30 days & $53.4 \pm 10.1 \mathrm{~A}, \mathrm{a}$ & $11.5 \pm 4.3$ A.a & \\
\hline \multirow{3}{*}{$\begin{array}{l}\text { Structur } \\
\text { 2C (ST2) }\end{array}$} & 1 day & $30.5 \pm 3.6 \mathrm{~B}, \mathrm{a}$ & $4.2 \pm$ & \multirow{3}{*}{$\begin{array}{c}0.30 \\
\pm 0.01 \mathrm{a}\end{array}$} \\
\hline & 15 days & $32.3 \pm 5.7 \mathrm{BC}, \mathrm{a}$ & $4.9 \pm 1.2$ & \\
\hline & 30 days & $39.9 \pm 9.8 \mathrm{~A}, \mathrm{a}$ & $5.2 \pm 1.7$ B.a & \\
\hline \multirow{3}{*}{$\begin{array}{l}\text { ProviPlast } \\
\text { (PVP) }\end{array}$} & 1 day & $27.5 \pm 3.8 \mathrm{~B}, \mathrm{ab}$ & $4.5 \pm 7.3$ В.a & \multirow{3}{*}{$\begin{array}{c}0.24 \\
\pm 0.01 \mathrm{~b}\end{array}$} \\
\hline & 15 days & $25.7 \pm 4.8 \mathrm{C}, \mathrm{b}$ & $4.7 \pm 0.7$ B.a & \\
\hline & 30 days & $37.4 \pm 6.4$ A,a & $4.9 \pm 0.8$ B.a & \\
\hline
\end{tabular}

Uppercase letters in rows and lowercase letters in columns indicate statistically significant differences.
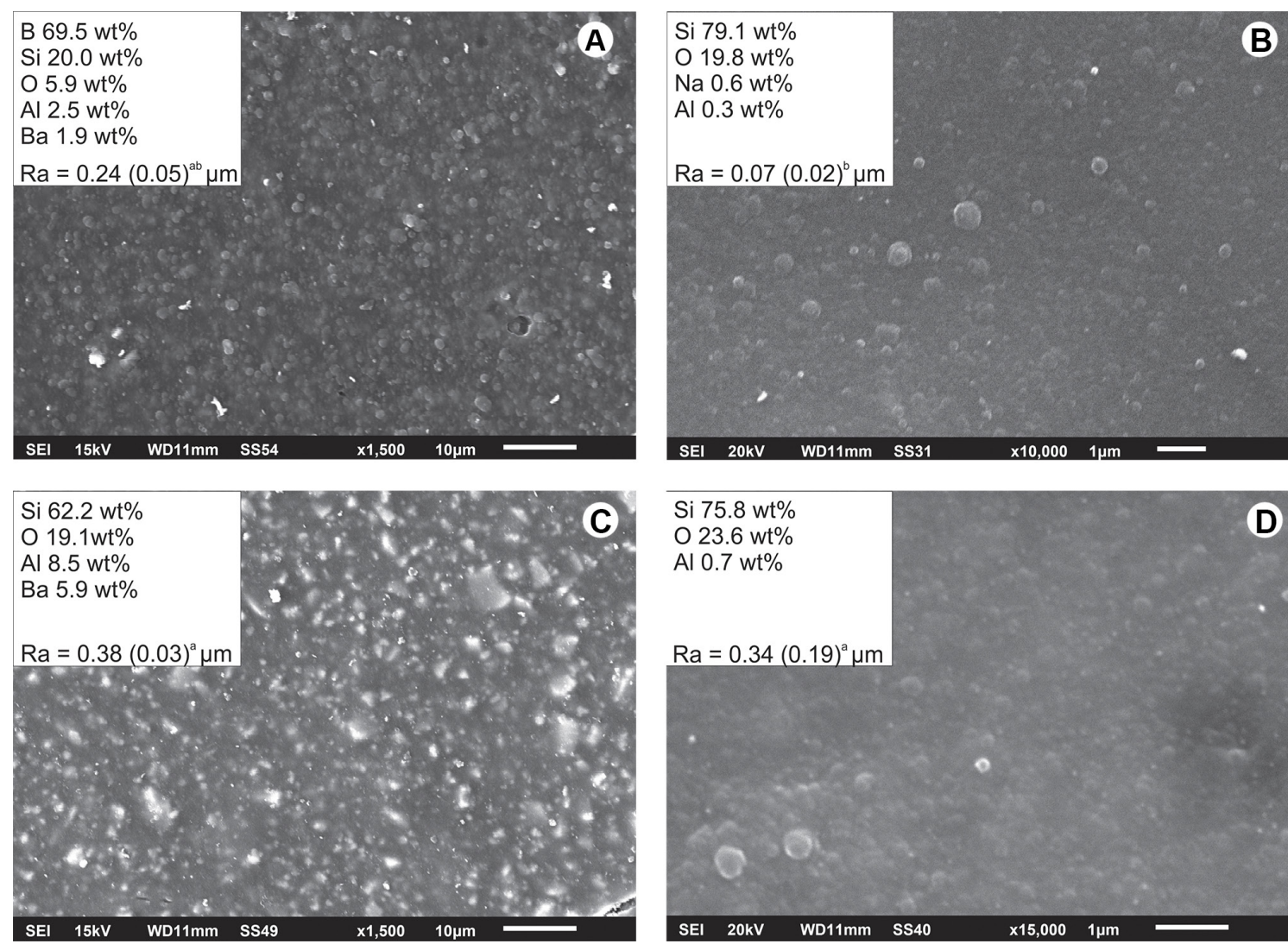

Fig. 2. SEM images showing surface morphology of bis-acryl composite resins and means $\pm 95 \%$ confidence intervals for surface roughness (Ra, $\mu \mathrm{m})$. A: SYS; B: PT4; C: ST2; D: PVP. Different magnifications were used. Results of EDS analysis (wt $\%)$ suggest that inorganic phase of Systemp CAB II is composed by borosilicate glass particles, whereas inorganic phase of other materials is predominantly composed by silica particles. 
A
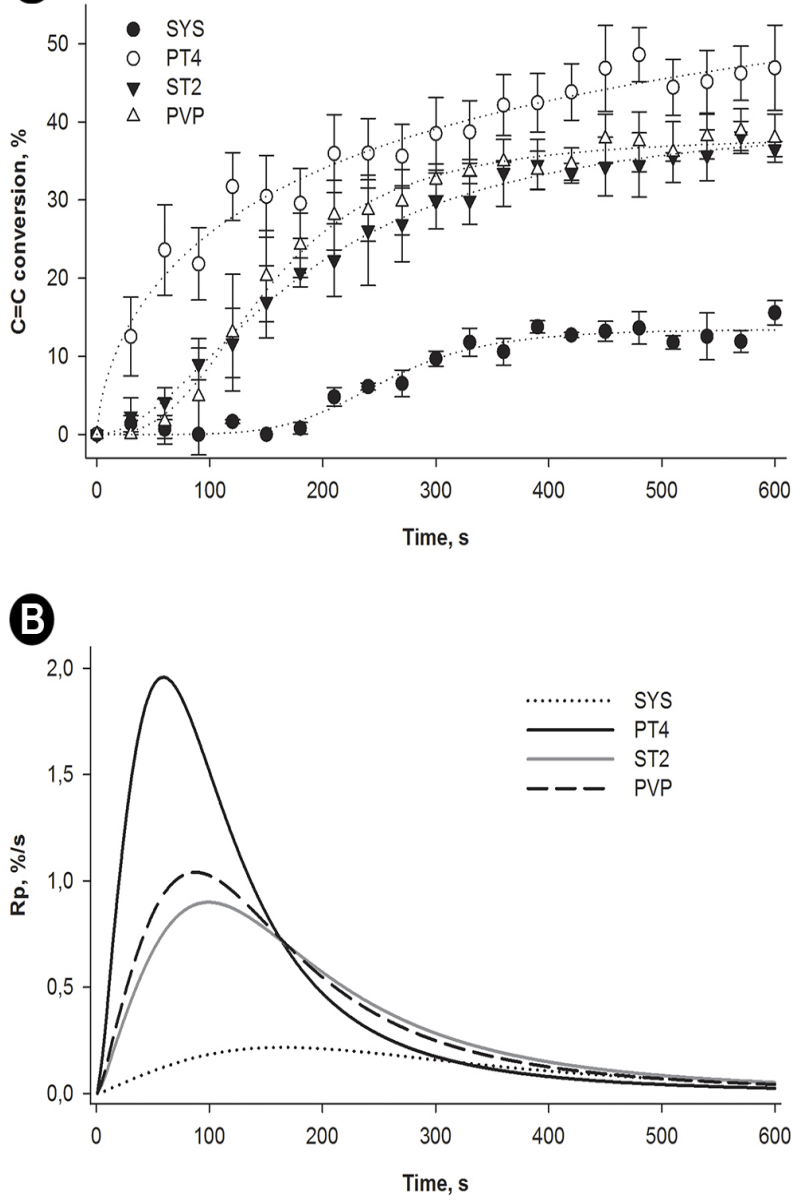

Fig. 4. Polymerization kinetics $(\mathrm{A})$ and rate $(\mathrm{Rp})$ profiles $(\mathrm{B})$ of bis-acryl composite resins. undergoes perceptible optical alteration with time may compromise the long-term esthetics in interim prostheses, particularly in anterior rehabilitations that require many clinical sessions (11). The change in optical characteristics during storage may be accounted as an effect of water sorption and oxidation of unreacted monomers and polymerization promoters entrapped in the crosslinked network (17). Swelling may lead to polymer relaxation by a plasticizing effect of water, making the polymer chains generally more mobile, facilitating the elution of unbound species with time, including unreacted monomers, pigments and even fillers. PVP, for instance, showed lower PT after 15 days of storage compared with 30 days. This finding may be explained by the oxidized agents in the early swelling stages and leaching of these species in later times. A similar phenomenon could explain the slight, but sometimes significant changes in fluorescence observed for some materials as function of water storage time.

Another factor that may interfere with the optical properties is surface roughness. The relationship between surface roughness and color stability of dental materials was shown in previous studies $(12,13)$. The surfaces of ST2 and PVP were significantly rougher compared with PT4, a material that showed stable optical properties in this study. The SEM analysis also indicated that PT4 and PVP have smaller particles than the other bis-acryl composite resins, and that these fillers are likely silica nanoparticles. Nanoparticles are probably used to improve surface smoothness and gloss, and enhance esthetics, although the effect of nanoparticles on those aspects in dental resin composites is arguable (18). Different magnifications in the SEM analysis were used to allow observing the filler particles and their interaction with the polymer matrix. For $P V P$, the presence of high nanoparticle load may be the cause of its high viscosity, which could not be tested in the rheometer. The other materials showed a typical thixotropic behavior with reduced viscosity with time under constant shear rate. Thixotropy is important to allow provisional materials to be applied to silicone molds, for instance, without spontaneous flow before being hand-pressed against
Fig. 5. Results for failure analysis of specimens retrieved from biaxial flexure test. Specimens failed generating no fragments (only cracks) or presented catastrophic failures (presence of two or more fragments). 
the dental structures.

The mechanical behavior was also dependent on the tested material. After 30 days of water storage, none of the bis-acryl composite resins reduced significantly its mechanical behavior compared with groups tested after 24 h. In some cases, like for SYS, the mechanical results were even higher after storage. This may be explained by the increased $\mathrm{C}=\mathrm{C}$ conversion and polymer crosslinking that may take place with time. The results for degree of $\mathrm{C}=\mathrm{C}$ conversion up to $10 \mathrm{~min}$ were generally low for all materials, with room for additional polymerization afterwards. Previous studies have observed similar findings related to increased mechanical strength for bis-acryl and other provisional resin-based materials, as function of different storage conditions (6-8). PT4 was the material that showed the earliest gelation; the working time of PT4 should be evaluated in further studies since higher temperature in the oral environment may lead to enhanced $\mathrm{Rp}$.

In the failure analysis after the biaxial flexure test, catastrophic failures were observed for SYS much more frequently after 15 and 30 days of storage compared with $24 \mathrm{~h}$. PT4 also had more catastrophic failures occurring after 30 days storage time. This is an indication that water

occur primarily through the polymer matrix between filler particles. The long-term interaction between inorganic fillers is also a factor affecting the mechanical performance of resin-based composites (19). Water sorption and swelling effects may consequently interfere with the overall polymer strength. The $E_{f}$ of SYS was significantly higher after 30 days compared with $24 \mathrm{~h}$. This behavior could pose a risk for increased mechanical failures for provisional prostheses involving multiple teeth and pontic width exceeding one unit, although just now this is only speculation. ST2 and PVP showed lower $E_{f}$ than the other bis-acryl composite resins and most of their failures were not catastrophic, only generated cracks.

In conclusion, the properties and characteristics tested in this study were largely influenced by the tested material. Depending on the provisory requirements, some materials could be better suited than others. Therefore, a case-bycase analysis should be carried out when considering the clinical performance of bis-acryl provisional materials. In general, Protemp 4 and Systemp C\&B II showed better performance after storage for 30 days. However, the analyses reported here may only allow comparing the in vitro performance of the materials tested, while it is still difficult to suggest if all or none of the bis-acryl composite resins reached minimum performance for clinical use as regards each investigated property. Interim restorations should be monitored closely when exceeding 30 days of clinical service. In addition, provisional restorations must take into account all biological, mechanical, superficial and esthetic requirements for success.

\section{Resumo}

Este estudo investigou o desempenho in vitro de quatro resinas compostas bisacrílicas comerciais: Systemp C\&B II (SYS, Ivoclar Vivadent), Protemp 4 (PT4, 3M ESPE), Structur 2C (ST2, Voco) e ProviPlast (PVP, Biodinamica). A caracterização envolveu análises ópticas (estabilidade de cor, parâmetro de translucidez, fluorescência), de superficie (rugosidade, morfologia e composição elementar), físico-quimicas (viscosidade, cinética de polimerização) e mecânicas (razão de Poisson, resistência à flexão biaxial, módulo de elasticidade). A maioria dos testes foram realizados após $24 h$, enquanto análises ópticas e mecânicas foram realizadas após armazenamento em água a $37{ }^{\circ} \mathrm{C}$ por 1,15 e 30 dias. Os dados foram analisados estatisticamente $(\alpha=0,05)$. Grande parte dos resultados foi dependente do material. SYS e PT4 mostraram estabilidade de cor e translucidez ao longo do tempo. Todos os materiais apresentaram fluorescência similar ou maior que o esmalte humano. SC2 e PVP apresentaram superfícies mais rugosas que os outros materiais. Menores particulas de carga foram observadas na superficie de PT4 e PVP comparadas às partículas mais irregulares de ST2 e SYS. As leituras de viscosidade indicaram comportamento tixotrópico para todos os materiais testados. SYS teve a menor e PT4 o maior grau de conversão de $\mathrm{C}=\mathrm{C}$ após $10 \mathrm{~min}$. Na cinética de polimerização, PT4 teve a maior taxa máxima de polimerização e atingiu mais cedo a transição entre autoaceleração e autodesaceleração da polimerização. PT4 e SYS apresentaram resistência à flexão e módulo de elasticidade significativamente maiores que ST2 e PVP na maioria dos periodos de armazenamento. Resultados da razão de Poisson variaram entre os materiais. Periodos mais longos de armazenamento foram em geral associados a maior frequência de falhas catastróficas nos testes de flexão. Em conclusão, o desempenho das resinas compostas bisacrilicas variou amplamente entre os materiais.

\section{Acknowledgements}

The authors thank the manufacturers for providing the materials used for testing, FO-USP, Brazil (Dr. Erick Silva and Prof. Paulo Cesar) for assistance with fluorescence analysis, FOSJC-UNESP, Brazil (Prof. Alexandre Borges) for assistance with Poisson ratio analysis and CEME-SUL FURG, Brazil for assistance with scanning electron microscopy.

\section{References}

1. Meereis CT, de Souza GB, Albino LG, Ogliari FA, Piva E, Lima GS. Digital smile design for computer-assisted esthetic rehabilitation: Two-year follow-up. Oper Dent 2016;41:E13-E22.

2. Burns DR, Beck DA, Nelson SK, Committee on Research in Fixed Prosthodontics of the Academy of Fixed Prosthodontics. A review of selected dental literature on contemporary provisional fixed prosthodontic treatment: report of the Committee on Research in Fixed Prosthodontics of the Academy of Fixed Prosthodontics. J Prosthet Dent 2003;90:474-497.

3. Akova T, Ozkomur A, Uysal $\mathrm{H}$. Effect of food-simulating liquids on the mechanical properties of provisional restorative materials. Dent Mater 2006;22:1130-1134.

4. Balkenhol M, Ferger P, Mautner MC, Wöstmann B. Provisional crown and fixed partial denture materials: mechanical properties and degree of conversion. Dent Mater 2007;23:1574-1583.

5. Vaidyanathan T, Vaidyanathan J, Manasse M. Analysis of stress relaxation in temporization materials in dentistry. Dent Mater 2015;31:e55-e62.

6. Kerby RE, Knobloch LA, Sharples S, Peregrina A. Mechanical properties 
of urethane and bis-acryl interim resin materials. J Prosthet Dent 2013;110:21-28

7. Knobloch LA, Kerby RE, Pulido $T$, Johnston WM. Relative fracture toughness of bis-acryl interim resin materials. J Prosthet Dent 2011;106:118-125.

8. Thompson GA, Luo Q. Contribution of postpolymerization conditioning and storage environments to the mechanical properties of three interim restorative materials. J Prosthet Dent 2014;112:638-648.

9. Yao J, Li J, Wang $Y$, Huang $H$. Comparison of the flexural strength and marginal accuracy of traditional and CAD/CAM interim materials before and after thermal cycling. J Prosthet Dent 2014;112:649-657.

10. Kurtzman GM. Crown and bridge temporization part 1: Provisional materials. Inside Dentistry, 2008. Available at www.dentalaegis.com/ id/2008/09/crown-and-bridge-temporization-part-1-provisionalmaterials <last access 0ctober 26, 2016>.

11. Bayindir F, Kürklü D, Yanikoğlu ND. The effect of staining solutions on the color stability of provisional prosthodontic materials. J Dent 2012;40(Suppl 2):e41-e46.

12. Moris IC, Oliveira JE, Faria AC, Ribeiro RF, Rodrigues $R C$. In vitro fit and cementation resistance of provisional crowns for single implantsupported restorations. Braz Dent J 2015;26:468-473.

13. Rutkunas V, Sabaliauskas V, Mizutani H. Effects of different food colorants and polishing techniques on color stability of provisional prosthetic materials. Dent Mater J 2010;29:167-176.
14. CIE technical report: colorimetry. CIE Publication 15.3. Vienna, Austria: CIE Central Bureau; 2004.

15. Sharma G, Wu W, Dalal EN. The CIEDE2000 color-difference formula: Implementation notes, supplementary test data, and mathematical observations. Color Res Appl 2005;30:21-30.

16. Xia W, Mohd Razi MR, Ashley P, Abou Neel EA, Hofmann MP, Young AM. Quantifying effects of interactions between polyacrylic acid and chlorhexidine in dicalcium phosphate-forming cements. J Mater Chem B 2014;2:1673-1680.

17. Salgado VE, Albuquerque PP, Cavalcante LM, Pfeifer CS, Moraes RR, Schneider LF. Influence of photoinitiator system and nanofiller size on the optical properties and cure efficiency of model composites. Dent Mater 2014;30:e264-271.

18. Kaizer MR, de Oliveira-Ogliari A, Cenci MS, Opdam NJ, Moraes RR. Do nanofill or submicron composites show improved smoothness and gloss? A systematic review of in vitro studies. Dent Mater 2014;30:e4178.

19. Kaizer MR, Almeida JR, Gonçalves AP, Zhang Y, Cava SS, Moraes RR. Silica coating of nonsilicate nanoparticles for resin-based composite materials. J Dent Res 2016;95:1394-1400.

Received November 19, 2016 Accepted February 23, 2017 